\title{
ATTRIBUTES OF ISLAMIC BANK SERVICE QUALITY: A SURVEY TO MAP METROPOLITAN CUSTOMER SATISFACTION
}

\author{
Ade Sofyan Mulazid* \\ Universitas Islam Negeri Syarif Hidayatullah Jakarta \\ M. Arief Mufraini \\ Universitas Islam Negeri Syarif Hidayatullah Jakarta \\ Desmadi Saharuddin \\ Universitas Islam Negeri Syarif Hidayatullah Jakarta \\ Ahmad Tibrizi Soni Wicaksono \\ Universitas Islam Negeri Maulana Malik Ibrahim Malang
}

\begin{abstract}
This study aims to analyze service quality of Islamic Banking in Jakarta. Data were randomly obtained from metropolitan customers with the CARTER approaches, which comprises of Compliance, Assurance, Reliability, Tangibles, Empathy, and Responsiveness used to determine customer satisfaction index and importance performance analysis. Although the overall result showed that metropolitan customers of Islamic banks are satisfied, gaps were found on attributes of the services provided. Therefore, continuous improvement is needed to ensure the proper use of information technology (e-Banking), the ability of banks in responding to problems and complaints quickly, and the hospitality of employees while attending to customers.
\end{abstract}

Keywords: Compliance; Assurance; Reliability; Tangibles; Empathy.

Received: 24 October 2019

Accepted: 4 May 2020

\section{INTRODUCTION}

Traditional strategic marketing is comprises of segmentation, targeting, and positioning (STP). It is also based on the identifying viable consumer segments to engage in mutually beneficial transactions. Marketing literature, however, reveals that women, minorities, and other ethnic groups, have been marginalized in terms of strategic marketing practice, as well as those categorized as “critical mass" (El-Bassiouny, 2014; Emslie, Bent, \& Seaman, 2007; Muley, 2009; Nederveen Pieterse, 2009; Sinclair, 2009).

\footnotetext{
* Corresponding author: Faculty of Economics and Business, State Islamic University of Syarif Hidayatullah Jakarta, Indonesia, WhatsApp \& Phone: (62)813 8136 7407, and e-mail: adesofyanmulazid@uinjkt.ac.id.
} 
Apart from Muslim-majority countries like Malaysia, Turkey, Iran, and Egypt, the size of the Muslim population in other parts of the world is growing rapidly. In the UK, the Muslim population is forecasted to continue growing at a $6.7 \%$ rate, which is likely to reach $50 \%$ of the population by 2050 (El-Bassiouny, 2014; Ferguson, 2011; Saharuddin et al. 2019). The number of Muslims is approximately 8 million in the United States and 17 million in Western Europe (El-Bassiouny, 2014; Grim \& Karim, 2011; Kettani, 2019; Siddiqui \& Ba-Yunus, 1998). The size and growth rate of the Muslim community has some observers speculating if the potential change in demographics might result in conflict (El-Bassiouny, 2014; Ferguson, 2011). However, the events of September 11, 2001, underscore the relevance of such inquiry (Cole, 2009; Haleem, 2011). Misperceptions can certainly lead to a risk of polarization and global divides (El-Bassiouny, 2014; Nederveen Pieterse, 2009).

According to the Central Intelligence Agency (2019), Indonesia is a country with the world's fourth-largest population and counts as the largest Muslim community worldwide. The country ranks sixth on the lists of Islamic financial index. Besides, Smart Consulting in 2016 reports that the Indonesian Islamic banks asset is approximately USD 22 billion and ranked seventh globally. Financial Services Authority explains (2019) that the total assets of Islamic banks in Indonesia is $5.95 \%$ of the Banking sector in Indonesia. However, over the past 5 years, the Indonesian Islamic Banks have shown a positive trend with a yearly increase in total assets, the number of offices, and workers. Currently, various communities have started to be introduced to Islamic-based mortgage, insurance, investment, and rural banking services. This started with the establishment of Bank Muamalat in 1991. Therefore, it is interesting to see the application of good service quality in the Islamic banking industry activity because it is one of the spearheads in increasing industrial growth.

Service offices of Indonesian Islamic bank in 2012 - 2019 grew in number, with 555 offices, culminating in 2,300 offices from 1,745. However, in 2015 and 2016, the number decreased by 173 and 5 offices, respectively, leading to a total of 1885 offices. On the other hand, the total number of offices on the Islamic bank business unit was stable from 2012 - 2013, with a total of 590 offices. However, the coming spin-off regulation in 2014 led to a significant yearly decrease. In 2012, the number of Islamic bank employee, increased by more than $100 \%$ in 2012 , leading to a total of 24,111 employed people. The year 2019 also experienced a significant increase in 54,840 people. During the last 3 years there were fluctuations in the budget allocated by Islamic banks for human capacity building. In addition, both Islamic bank (BUS) and Islamic business unit (UUS) experienced a decrease in budget allocation in 2016, by more than 64 billion rupiahs.

All vital activities such as government administration activities, private sector, office centers, and business activities are centralized in Jakarta, as the capital city of the Republic of Indonesia. In line with the development of the banking sector, Jakarta has become the best place for Islamic Banks. Financial Services Authority (2019) placed Jakarta as the largest of Islamic financial asset. (386,420 trillion), the largest of Islamic financing funds (152,903 trillion), and the largest of thirdparty funds (190,350 trillion) compared to other provinces in Indonesia. In 2019 the Islamic Banks in Jakarta almost contributed approximately $54,82 \%$ of the total assets in Indonesia with a total of 265 Islamic bank service offices. Rama's (2018) research on the Provincial Islamic Economic Indexation in Indonesia, put Jakarta at number eight.

In 2008, the Islamic Banking Directorate of Bank Indonesia revealed the grand strategy of Islamic bank market development through some programs such as, short of positioning, attribute of 
services, product, method of bidding, services and image, product and market development program. The functional and emotional benefits of the cosmopolite customer are considered to be utilized to create a better product. Moreover, Bank Indonesia also prioritizes service improvement program for reliability, assurance, tangibles, empathy, responsiveness, and public education and communication.

This research employed the quantitative approach to emphasize more on the gap quality of services as well as the perception and expectation of metropolitan customers in Jakarta. The scope of this study is to measure the level of customer importance on the quality of service, performance, and conformity provided by Islamic Bank. This research is focused in Jakarta because it is the center of Indonesian businesses, with the most substantial amount of third-party funds and money circulation. It is also an area with diverse societal characteristics.

\section{LITERATURE REVIEW}

Kotler \& Keller (2012) defined services as any intangible activity, benefit, or performance offered by one party to another without transfer of ownership. According to Wilson \& Frimpong (2004), service performance is defined as the customer's assessment of the superiority or privilege of a product or service. Previous research on services also shows that customers are attracted to the service provider's good service qualities (Bitner, 1990; Bitner et al. 1990; Lovelock \& Gummesson, 2004; Solomon, Michael, Surprenant et al. 1985). Lovelock \& Gummesson (2004) reported that customers tend to perceive the quality of service employees provide to represent the company. Therefore, employees need to demonstrate a good understanding of the service concept.

Ladhari (2009) stated that it is difficult to define and measure the quality of service. This has been debated over the past twenty years with a number of different "definitions" as to what is meant by the quality of service. According to Lewis (2010), service quality is defined as the extent to which services meet customer needs or expectations. The quality of service can be defined as the difference between customer expectations and perception (Lovelock \& Wright, 2007). Customer service quality, satisfaction, and loyalty are important factors for the sustainability of a bank. Therefore, banks need to always provide the perfect quality service for each customer to fulfill their expectations (Rasoul \& Mohammad, 2011).

Moeller (2010) and Zhu et al. (2002) stated that it is difficult to measure the objective quality of service due to its unique characteristics. Researchers have used different instruments to measure the service quality index, with the SERVQUAL scale as the most widely used. SERVQUAL instruments have expanded widely since the mid-80s. However, many researchers have criticized its dimensions as a measure of service quality instruments. Buttle (1996) criticizes the theory and operational of the instrument due to its ability to describe economic stability. Buttle stated that SERVQUAL focuses on the service delivery process is not the result of a direct service approach. Therefore, its dimensions are not necessarily acceptable to everyone. Critics on operational implementation stated that SERVQUAL fails to measure the quality of service as a whole. Secondly, 4 or 5 items cannot describe the variability in each service quality dimension. Thirdly, consumer ratings for service quality vary, and the scale of 7 points tends to fail, thereby, leading to saturated and biased instruments. 
To cover the weaknesses in SERVQUAL, Othman \& Owen (2001a) added an element of compliance to the quality dimensions of service earlier studied by Parasuraman, Zeithaml \& Berry (1988). According to Akhtar \& Zaheer (2014), research on service quality in Islamic banking has different characteristics due to the various cultures in countries. Therefore, it is important to develop instruments to measure the quality of services related to the culture, country, and sociocultural character (Furrer et al. 2000; Jabnoun \& Khalifa, 2005; Klementova et al. 2015).

Therefore, to resolve the problem associated with this unique characteristic, Othman \& Owen (2001b) developed a CARTER model that measures the quality of service to customer satisfaction in Islamic banking. This model consists of five dimensions, namely, compliance, assurance, reliability, tangible, empathy, and responsive (CARTER).

According to Chapra (2000), satisfaction is the level of consumer feeling after comparing with expectations. When a consumer are satisfied with the value given to the product or service, they are likely to return. Meanwhile, Masood et al. (2009) stated that the names of Islamic banks, its reputation, customer confidentiality, interaction, and physical aspects such as internal layout, the suitability of furniture, and architectural design, has the ability to improve customer satisfaction and preference.

Riaz et al. (2017) reported that consumer perceptions in Islamic banking products and services are the views formed based on the level of awareness, knowledge, and religiosity. Customer perceptions increase with the implementation of better Islamic marketing, planning and enhance cooperation between industry and academia in making innovative products for consumers. However, Gait \& Worthington (2009) stated that customers perceive religiosity as an important factor in forming a perception. Some factors that also influence customers' perception are the cost of banking services, quality, and reputation. Furthermore, certain services provided by other companies can have an impact on consumer perceptions regarding quality. The researcher believes that perception and expectation are relatively strong concepts (Kwak, 2017; Yousfani et al. 2019; Zeithaml et al. 1985). Customer perceptions are the result of how customers recognize the quality of service, while expectations are formed through others' influence.

\section{METHODHOLOGY}

Islamic banks comprise of continuous growt of customers. The random sampling method was used to obtain data from 132 customers chosen according to the characteristics to be studied. This sample is also in line with research conducted by Sekaran (2006), which stated that the appropriate sample size is between 30 to 500 .

Data is the variable depiction that was studied and used to prove the hypothesis. The two essential conditions that apply to a questionnaire are validity and reliability test. Customer Satisfaction Index (CSI) and Importance Performance Analysis (IPA) are used to analyze this research. Kotler (2000) explained that one of the analyses used to assess the 5 elements of service quality or to meet the company's performance with great customer expectation is to determine the steps needed for continuous improvement. Bhote (1996) also stated that the customer satisfaction index is used to determine the overall attributes of a product or service, which is quantitatively measured. 
The CARTER approach is used to measure the compliance, assurance, reliability, tangibles, empathy, and responsiveness of Islamic banks. The range of calculation is as follows: CSI $81 \%$ $100 \%$ is very satisfied, $66 \%-80,99 \%$ is satisfied, $51 \%-65,99 \%$ is quite satisfied, $35 \%-50,99 \%$ is less satisfied and $0-34,99 \%$ is not satisfied. The CSI model is a structural model based on the assumption that customer satisfaction is caused by perceived quality (PQ), perceived value (PV), customer expectations, and corporate image. These factors are central to the overall customer satisfactions and also be used to estimate whether the customer is satisfied (Prasadh \& Suresh, 2017; Rajendran \& Suresh, 2017; Türkyilmaz \& Özkan, 2007).

\section{RESULTS AND DISCUSSION}

The validity test in this study is used to address the significance of person's correlation at 0.000 , with all items being valid. Table 1 shows the value of Cronbach's Alpha of all variables. It is concluded that the questionnaire are reliable, when all variables have a value of Cronbach's Alpha greater than 0.60 .

Table 1: Reliability Test Result per Variable

\begin{tabular}{|c|c|c|c|}
\hline No & Variable & Cronbach's Alpha & $\mathrm{N}$ of Items \\
\hline 1 & Assurance & 0.906 & 10 \\
\hline 2 & Reliability & 0.886 & 10 \\
\hline 3 & Tangible & 0.873 & 10 \\
\hline 4 & Empathy & 0.909 & 10 \\
\hline 5 & Responsiveness & 0.911 & 10 \\
\hline 6 & Compliance & 0.937 & 10 \\
\hline
\end{tabular}

The distributed questionnaire consists of 30 attributes, which are measured to construct the importance and performance. The calculation of CSI (71.87) indicates that the criteria of customer satisfaction at Islamic Banks service office in Jakarta are in satisfied. Tabel 2 shows that compliance, assurance, reliability, tangibles, empathy, and responsiveness of Islamic banks is satisfactory due to customer expectation.

Table 2: Customer Satisfaction Index

\begin{tabular}{clccc}
\hline \hline Code & \multicolumn{1}{c}{ Attribute } & Importance Rate & Performance Rate & Score \\
\hline A1 & $\begin{array}{l}\text { Hospitality of employees in serving } \\
\text { customers }\end{array}$ & 3.71 & 3.58 & 13.28 \\
A2 & $\begin{array}{l}\text { Courtesy of employees in serving } \\
\text { customers }\end{array}$ & 3.88 & 3.71 & 14.39 \\
A3 & $\begin{array}{l}\text { Knowledge of employees concerning } \\
\text { Islamic bank }\end{array}$ & 3.61 & 3.56 & 12.85 \\
A4 & $\begin{array}{l}\text { Honesty of employees in every } \\
\text { transaction } \\
\text { Akills of employees in handling }\end{array}$ & 3.95 & 3.63 & 14.34 \\
& \begin{tabular}{l} 
customers' complaints \\
\hline
\end{tabular}
\end{tabular}




\begin{tabular}{|c|c|c|c|c|}
\hline Code & Attribute & Importance Rate & Performance Rate & Score \\
\hline A6 & Accuracy of working hours & 3.52 & 3.48 & 12.25 \\
\hline A7 & Ease in implementation of transactions & 3.66 & 3.59 & 13.14 \\
\hline A8 & $\begin{array}{l}\text { Accurate recording of customer } \\
\text { transactions }\end{array}$ & 3.76 & 3.63 & 13.65 \\
\hline A9 & Seriousness in processing financing & 3.53 & 3.47 & 12.25 \\
\hline A10 & Offering Islamic bank products & 3.79 & 3.74 & 14.17 \\
\hline A11 & $\begin{array}{l}\text { Use of equipment and technology in } \\
\text { bank operations }\end{array}$ & 3.71 & 3.45 & 12.80 \\
\hline A12 & Existence of a parking lot & 3.37 & 3.4 & 11.46 \\
\hline A13 & Interior and exterior arrangement & 3.25 & 3.39 & 11.02 \\
\hline A14 & $\begin{array}{l}\text { Cleanliness and tidiness of employees' } \\
\text { outfit }\end{array}$ & 3.87 & 3.63 & 14.05 \\
\hline A15 & $\begin{array}{l}\text { Placement of brochures, well-ordered } \\
\text { deposit and withdrawal slips }\end{array}$ & 3.35 & 3.53 & 11.83 \\
\hline A16 & Giving attention to customers & 3.59 & 3.49 & 12.53 \\
\hline A17 & Responsible for customer safety & 3.84 & 3.74 & 14.36 \\
\hline A18 & Fair service to every customer & 3.89 & 3.67 & 14.28 \\
\hline A19 & $\begin{array}{l}\text { Strategic location determination for } \\
\text { transacting customers }\end{array}$ & 3.52 & 3.43 & 12.07 \\
\hline $\mathrm{A} 20$ & Information technology with e-Banking & 3.75 & 3.57 & 13.39 \\
\hline A21 & $\begin{array}{l}\text { The ability of banks to respond to } \\
\text { problems arising }\end{array}$ & 3.71 & 3.48 & 12.91 \\
\hline A22 & $\begin{array}{l}\text { The ability of employees to } \\
\text { communicate with customers }\end{array}$ & 3.71 & 3.59 & 13.32 \\
\hline A23 & $\begin{array}{l}\text { The bank's ability to respond quickly to } \\
\text { customer complaints }\end{array}$ & 3.69 & 3.51 & 12.95 \\
\hline A24 & $\begin{array}{l}\text { Employee responsiveness in bank } \\
\text { operational matters }\end{array}$ & 3.51 & 3.59 & 12.60 \\
\hline A25 & $\begin{array}{l}\text { Speed of employees in serving customer } \\
\text { transactions }\end{array}$ & 3.71 & 3.67 & 13.62 \\
\hline A26 & $\begin{array}{l}\text { No riba, gharar, or maisir in the } \\
\text { transaction }\end{array}$ & 3.91 & 3.75 & 14.66 \\
\hline A27 & $\begin{array}{l}\text { Running a business based on halal } \\
\text { benefits }\end{array}$ & 3.78 & 3.7 & 13.99 \\
\hline A28 & $\begin{array}{l}\text { Carrying out the mandate that is trusted } \\
\text { by customers }\end{array}$ & 3.82 & 3.71 & 14.17 \\
\hline A29 & $\begin{array}{l}\text { Providing accurate \& up-to-date } \\
\text { information to customers }\end{array}$ & 3.64 & 3.6 & 13.10 \\
\hline \multirow[t]{4}{*}{ A30 } & Management of trustworthy zakat & 3.93 & 3.79 & 14.89 \\
\hline & Total & 110.66 & & 397.68 \\
\hline & Calculation & & & \\
\hline & $\begin{array}{lll}\text { CSI } & = & 397.68 \\
& \times 100 & \\
& & (5 \times 110.66)\end{array}$ & & & \\
\hline
\end{tabular}




\begin{tabular}{lccccc}
\hline \hline Code & Attribute & Importance Rate & Performance Rate & Score \\
\hline \multirow{3}{*}{39768} & & $397.68 \times 100=$ & & \\
& $=$ & $39.768:(553.3)$ & & \\
& $=$ & $\mathbf{7 1 . 8 7 \%}$ & & \\
\hline \hline
\end{tabular}

The performance analysis test is carried out to determine the level of conformity, with the rate divided to determine the priority scale (Yola \& Budianto, 2013). The levels of conformity of all attributes are good enough, on average $97.43 \%$, with the value of all conformity close to $100 \%$ due to a $2.57 \%$ gap. The attribute is considered to have met expectations on the importance of consumers. Some attributes have shown the conformity level above $90 \%$ and $97.43 \%$, as shown in table 3 .

Table 3: Importance Performance Analysis: Conformity Rate

\begin{tabular}{|c|c|c|c|c|}
\hline $\begin{array}{c}\text { Code of } \\
\text { Attribute }\end{array}$ & Attribute & $\begin{array}{c}\text { Performance } \\
\text { Rate }\end{array}$ & $\begin{array}{c}\text { Importance } \\
\text { Rate }\end{array}$ & $\begin{array}{c}\text { Conformity } \\
\text { Rate }\end{array}$ \\
\hline A 1 & $\begin{array}{l}\text { Hospitality of employees in } \\
\text { serving customers }\end{array}$ & 537 & 557 & 96.41 \\
\hline A 2 & $\begin{array}{l}\text { Courtesy of employees in } \\
\text { serving customers }\end{array}$ & 556 & 582 & 95.53 \\
\hline A 3 & $\begin{array}{l}\text { Knowledge of employees } \\
\text { concerning Islamic bank }\end{array}$ & 534 & 542 & 98.52 \\
\hline A 4 & $\begin{array}{l}\text { Honesty of employees in every } \\
\text { transaction }\end{array}$ & 544 & 593 & 91.74 \\
\hline A 5 & $\begin{array}{l}\text { Skills of employees in handling } \\
\text { customers' complaints }\end{array}$ & 541 & 555 & 97.48 \\
\hline A 6 & Accuracy of working hours & 522 & 528 & 98.86 \\
\hline A 7 & $\begin{array}{l}\text { Ease in implementation of } \\
\text { transactions }\end{array}$ & 538 & 549 & 98.00 \\
\hline A 8 & $\begin{array}{l}\text { Accurate recording of customer } \\
\text { transactions }\end{array}$ & 545 & 564 & 96.63 \\
\hline A 9 & $\begin{array}{l}\text { Seriousness in processing } \\
\text { financing }\end{array}$ & 520 & 530 & 98.11 \\
\hline A 10 & Offering Islamic bank products & 561 & 568 & 98.77 \\
\hline A 11 & $\begin{array}{l}\text { Use of equipment and } \\
\text { technology in bank operations }\end{array}$ & 517 & 556 & 92.99 \\
\hline A 12 & Existence of a parking lot & 510 & 505 & 100.99 \\
\hline A 13 & Interior and exterior arrangement & 509 & 487 & 104.52 \\
\hline A 14 & $\begin{array}{l}\text { Cleanliness and tidiness of } \\
\text { employees' outfit }\end{array}$ & 544 & 580 & 93.79 \\
\hline A 15 & $\begin{array}{l}\text { Placement of brochures, well- } \\
\text { ordered deposit and withdrawal } \\
\text { slips }\end{array}$ & 530 & 503 & 105.37 \\
\hline A 16 & Giving attention to customers & 523 & 539 & 97.03 \\
\hline A 17 & Responsible for customer safety & 561 & 576 & 97.40 \\
\hline
\end{tabular}




\begin{tabular}{|c|c|c|c|c|}
\hline $\begin{array}{c}\text { Code of } \\
\text { Attribute }\end{array}$ & Attribute & $\begin{array}{l}\text { Performance } \\
\text { Rate }\end{array}$ & $\begin{array}{l}\text { Importance } \\
\text { Rate }\end{array}$ & $\begin{array}{c}\text { Conformity } \\
\text { Rate }\end{array}$ \\
\hline A 18 & Fair service to every customer & 551 & 583 & 94.51 \\
\hline A 19 & $\begin{array}{l}\text { Strategic location determination } \\
\text { for transacting customers }\end{array}$ & 515 & 528 & 97.54 \\
\hline A 20 & $\begin{array}{l}\text { Information technology with e- } \\
\text { Banking }\end{array}$ & 535 & 562 & 95.20 \\
\hline A 21 & $\begin{array}{l}\text { The ability of banks to respond } \\
\text { to problems arising }\end{array}$ & 522 & 556 & 93.88 \\
\hline A 22 & $\begin{array}{l}\text { The ability of employees to } \\
\text { communicate with customers }\end{array}$ & 538 & 556 & 96.76 \\
\hline A 23 & $\begin{array}{l}\text { The bank's ability to respond } \\
\text { quickly to customer complaints }\end{array}$ & 526 & 553 & 95.12 \\
\hline A 24 & $\begin{array}{l}\text { Employee responsiveness in } \\
\text { bank operational matters }\end{array}$ & 539 & 526 & 102.47 \\
\hline A 25 & $\begin{array}{l}\text { Speed of employees in serving } \\
\text { customer transactions }\end{array}$ & 550 & 556 & 98.92 \\
\hline A 26 & $\begin{array}{l}\text { No riba, gharar, or maisir in the } \\
\text { transaction }\end{array}$ & 563 & 586 & 96.08 \\
\hline A 27 & $\begin{array}{l}\text { Running a business based on } \\
\text { halal benefits }\end{array}$ & 555 & 567 & 97.88 \\
\hline A 28 & $\begin{array}{l}\text { Carrying out the mandate that is } \\
\text { trusted by customers }\end{array}$ & 556 & 573 & 97.03 \\
\hline A 29 & $\begin{array}{l}\text { Providing accurate } \& \text { up-to-date } \\
\text { information to customers }\end{array}$ & 540 & 546 & 98.90 \\
\hline A 30 & $\begin{array}{l}\text { Management of trustworthy } \\
\text { zakat }\end{array}$ & 568 & 589 & 96.43 \\
\hline Total & & 16150 & 16595 & 97.43 \\
\hline
\end{tabular}

The average performance of each attribute is used to determine whether the performance of Islamic Bank services is good. It is used to compare the average performance of all attributes and their importance. Average performance is also used to determine the importance of the attribute. Table 4 shown that the average value and assessment level of all attributes is 3.59 , and 3.69 , respectively. The value is the midpoint used to determine the important of each service quality attributes of Islamic Banks. Further explanation of the analysis might refer to Quadrant column of Table 4 and the Cartesian diagram at Figure 1.

Table 4: Importance and Performance Rate

\begin{tabular}{cccccc}
\hline \hline $\begin{array}{c}\text { Code of } \\
\text { Attribute }\end{array}$ & $\begin{array}{c}\text { Performance } \\
\text { Rate }\end{array}$ & $\begin{array}{c}\text { Performance } \\
\text { Rate }\end{array}$ & $\begin{array}{c}\text { Importance } \\
\text { Score }\end{array}$ & $\begin{array}{c}\text { Importance } \\
\text { Score }\end{array}$ & Quadrant \\
\hline A 1 & 537 & 3.58 & 557 & 3.71 & A \\
A 2 & 556 & 3.71 & 582 & 3.88 & B \\
A 3 & 534 & 3.56 & 542 & 3.61 & C \\
A 4 & 544 & 3.63 & 593 & 3.95 & B \\
A 5 & 541 & 3.61 & 555 & 3.7 & B \\
\hline \hline
\end{tabular}




\begin{tabular}{cccccc}
\hline \hline $\begin{array}{c}\text { Code of } \\
\text { Attribute }\end{array}$ & $\begin{array}{c}\text { Performance } \\
\text { Rate }\end{array}$ & $\begin{array}{c}\text { Performance } \\
\text { Rate }\end{array}$ & $\begin{array}{c}\text { Importance } \\
\text { Score }\end{array}$ & $\begin{array}{c}\text { Importance } \\
\text { Score }\end{array}$ & Quadrant \\
\hline A 6 & 522 & 3.48 & 528 & 3.52 & C \\
A 7 & 538 & 3.59 & 549 & 3.66 & D \\
A 8 & 545 & 3.63 & 564 & 3.76 & B \\
A 9 & 520 & 3.47 & 530 & 3.53 & C \\
A 10 & 561 & 3.74 & 568 & 3.79 & B \\
A 11 & 517 & 3.45 & 556 & 3.71 & A \\
A 12 & 510 & 3.4 & 505 & 3.37 & C \\
A 13 & 509 & 3.39 & 487 & 3.25 & C \\
A 14 & 544 & 3.63 & 580 & 3.87 & B \\
A 15 & 530 & 3.53 & 503 & 3.35 & C \\
A 16 & 523 & 3.49 & 539 & 3.59 & C \\
A 17 & 561 & 3.74 & 576 & 3.84 & B \\
A 18 & 551 & 3.67 & 583 & 3.89 & B \\
A 19 & 515 & 3.43 & 528 & 3.52 & C \\
A 20 & 535 & 3.57 & 562 & 3.75 & A \\
A 21 & 522 & 3.48 & 556 & 3.71 & A \\
A 22 & 538 & 3.59 & 556 & 3.71 & B \\
A 23 & 526 & 3.51 & 553 & 3.69 & A \\
A 24 & 539 & 3.59 & 526 & 3.51 & D \\
A 25 & 550 & 3.67 & 556 & 3.71 & B \\
A 26 & 563 & 3.75 & 586 & 3.91 & B \\
A 27 & 555 & 3.7 & 567 & 3.78 & B \\
A 28 & 556 & 3.71 & 573 & 3.82 & B \\
A 29 & 540 & 3.6 & 546 & 3.64 & D \\
A 30 & 568 & 3.79 & 589 & 3.93 & B \\
Total & 16150 & 3.59 & 3.69 & - \\
\hline \hline
\end{tabular}

Quadrant A: This area contains attributes that are considered important by the Customers, although it is not in accordance with what they expected. Therefore, performance of attributes included in this quadrant needs to be improved. In contrast, Islamic banks need to perform continuous improvements on attributes with a low level of conformity (still below 100\%). This aims to increase the performance of these attributes in accordance with the expectations of the Customers. Attributes with the lowest level of compliance are prioritized and fixed. The attributes contained in quadrant A based on the priority order of improvement are as follows:

\section{- Attribute of employee courtesy in serving customers (A1)}

A1 attribute have average performance and importance rates 3.58 and 3.71, respectively. This attribute is below the average value of performance at 3.59 , while the customer's expectation is above 3.69. This attribute also shows that the conformity rate of $96.41 \%$, needs to be improved by Islamic Banks. This is in line with the research conducted by Mohamed \& Muneer (Janahi \& Al Mubarak, 2017), which shows that assurance (courtesy) has a great influence on customer satisfaction in Islamic banking. Therefore, it is expected that this attribute can be prioritized for immediate improvement. 
- Attribute of the Use of equipment and technology in bank operations (A 11)

A11 attribute has average performance and importance values of 3.45 and a 3.71, respectively. This attribute is below the average performance value of 3.59 and above 3.69 on the value of a customer's expectation. In addition, it shows a conformity rate of $92.99 \%$, which is less than $100 \%$. This is in line with the research conducted by Dangolani (2011) on the impact of information technology on the banking system in Iran. Dangolani also stated that information technology has a good impact on the banking industry. The research also shows that the use of information technology has a significant impact in saving time for customers and facilitates transactions.

- Attribute of Information technology with e-Banking (A 20)

A20 attribute has an average performance and importance values of 3.57 and 3.75, respectively. This attributes is below the average performance value of 3.59 and above 3.69 on the value of a customer's expectation. In addition, it shows a conformity rate of $95.20 \%$, which is less than $100 \%$. Therefore, this attribute needs to be improved because Islamic banks need to run its operational activities based on Islamic principles and information technology (Ahmadirezaei, 2011). Information technology has been basically used through 2 approaches in the field of Banking, namely a business process reengineering communication and connectivity approach. Information technology enables sophisticated product development and better market infrastructure.

- Attribute of the ability of banks in responding to problems arising (A 21)

A21 attribute has an average performance and importance rates of 3.48 and 3.71, respectively. It is less than average performance at 3.59, and above the average value of 3.69 of customer expectation. In addition, the attribute also shows the conformity value of $93.88 \%$, lower than $100 \%$. Therefore, the attribute needs to be immediate improved. Jahanshahi et al. (2011) stated that the quality of customer service, especially on responsiveness attributes directly affect satisfaction. Therefore, Islamic Bank needs to make a more serious correction on that aspect.

- Attribute of the bank's ability to respond quickly to customer complaints (A 23)

A23 attribute has an average performance and importance values of 3.51 and 3.69, respectively. The attribute rate is below the average value of performance at 3.59, and above the customer's importance at 3.69. In addition, the attribute also shows a conformity value of $95.12 \%$, lower than $100 \%$. Therefor, this attribute also needs to be improved. This is in line with the research conducted by Rasoul \& Mohammad (2011), which asserts that tangible, reliability, responsiveness, assurance, empathy, and compliance have a positive relationship and influence on the quality of service in Islamic banking.

Figure 1 shows all attributes contained in quadrant A, B, C and D in order of priority: 
Figure 1: Cartesian Diagram: Attributes in Quadrant

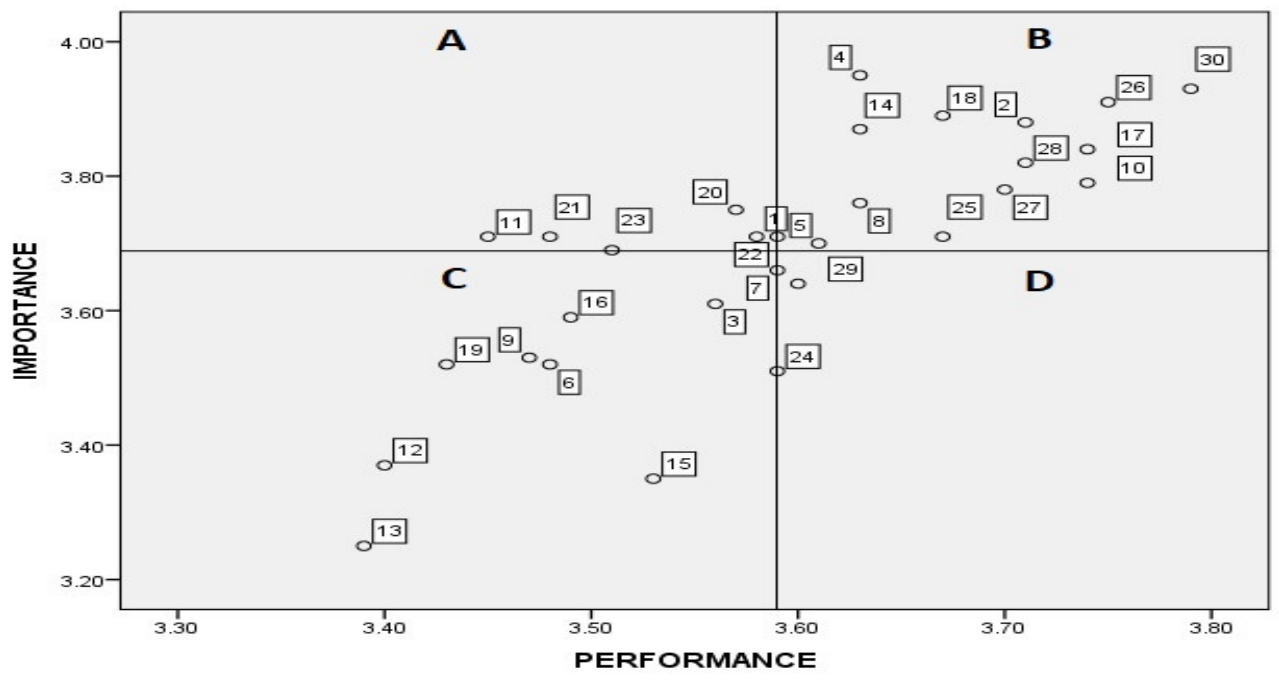

Quadrant B: This area contains attributes that are considered important by consumers in accordance with their expectations. The attributes included in this quadrant need to be maintained because they make the product superior to the consumer. The attributes and the level of conformity are: (A1) employee courtesy in serving the customer (95.53\%), (A4) honesty in carrying out transactions (91.74\%), (A5) employee's skill in handling customers' complaints $(97.48 \%)$, (A8) accurate recording of customer transactions $(96.63 \%)$, (A10) offering Islamic banking products (98.77\%), (A14) cleanliness and tidiness of employee's outfit (93.79\%), (A22) employee's ability to communicate with customers $(96.76 \%)$, (A25) employee's speed in serving customer transactions (98.92\%), (A26) there is no riba, gharar and maisir (96.08\%), (A27) running a business based on halal benefits (97.88\%), (A28) carrying out the mandates trusted by customers (97.03\%), (A30) management of trust worthy zakat (96.43\%).

Quadrant C: This area contains attributes that are considered less important by the consumer, and the performance is also not good. The act increasing attributes included in this quadrant is not a priority agenda due to its small impact on consumer. The attributes and the level of conformity include (A3) knowledge of employee concerning Islamic bank (98.52\%), (A6) accuracy of working hours $(98.86 \%$ ), (A9) seriousness in processing financing (98.11\%), (A12) existence of parking lot (100.99\%), (A13) interior and exterior arrangement (104.52\%), (A15) placement of brochures, well-ordered deposit and withdrawal slips (105.37\%), (A16) paying attention to customers (97.03\%), (A19) determination a strategic location for transacting customers $(97.54 \%)$.

Quadrant D: This area contains attributes that are considered unimportant by consumers and felt too much. The attributes included in this quadrant can be reduced in order for the company to save transaction costs (A7), which have average performance, importance, and conformity values of $3.59,3.66$ and $98 \%$, respectively. The attribute of employee responsiveness in bank operational matters (A24) has an average performance, importance, and conformity values of 3.59, 3.51, and $102.47 \%$, respectively. The attribute of providing accurate and up-to-date information to customers 
(A29) - have average performance, importance, and conformity values of 3.6, 3.64 and $98.90 \%$, respectively.

These three attributes are deemed less important by the customers of both Islamic and conventional banks. However, they are obliged to provide accurate and current information to customers and facilitate transactions with good responsiveness to banking operational activities. This is not separated from the rules of Bank Indonesia, which states that if banks do not provide accurate information, but provide difficult transactions, then it is bound to bear any loss incurred.

\section{CONCLUSION}

This research was conducted by examining 30 attributes of CARTER approach (Compliance, Assurance, Reliability, Tangibles, Empathy, and Responsiveness) using customer satisfaction index analysis. This technique shows that the level of customer satisfaction of Islamic Bank in Jakarta has a value of $71.87 \%$. It designates that the satisfaction criteria of the customer are in the satisfied category due to the services provided by Islamic Banks. Although the existing service has been running properly, it needs to be improved. From the results obtained through customer satisfaction index analysis, approximately $28.13 \%$ of service attributes have not been able to satisfy customers.

The test of importance and performance conformity using the Cartesian Diagram shows that there is a gap in the services provided by the Islamic banks. The result shows that the level of the services at Islamic Bank (BUS) is $97.43 \%$. Therefore, a gap of $2.57 \%$ needs to be improved, especially on attributes belonging to quadrant $\mathrm{A}$. Attribute performance is lower than what the consumers desire and expect. Therefore, banks need to take some action to improve their performance. Attributes that belong to Quadrant A are use of equipment and technology in bank operations, its ability to respond to customer complaints quickly, the use of information technology with e-Banking, and employee courtesy. All conformity values below 100\% also show that the attribute does not meet customers' expectations.

\section{REFERENCES}

Ahmadirezaei, H. (2011). The effect of information technology in Saderat banking system. Procedia - Social and Behavioral Sciences, 30, 23-26. https://doi.org/10.1016/j.sbspro.2011.10.005

Akhtar, A., \& Zaheer, A. (2014). Service quality dimensions development approach of islamic banks: A scale development approach. Global Journal of Management and Business Research: A Administration and Management, 14(5), 11-19.

Bhote, K. R. (1996). Beyond customer satisfaction to customer loyalty: The key to greater profitability. In American Management Association. American Management Association.

Bitner, M. J. (1990). Evaluating service encounters: The effects of physical surroundings and employee responses. Journal of Marketing, 54(2), 69. https://doi.org/10.2307/1251871

Bitner, M. J., Booms, B. H., \& Tetreault, M. S. (1990). The service encounter: Diagnosing favorable and unfavorable incidents. Journal of Marketing, 54, 71-84. 
Buttle, F. (1996). SERVQUAL: Review, critique, research agenda. European Journal of Marketing, 30(1), 8-32. https://doi.org/10.1108/03090569610105762

Central Intelligence Agency. (2019). The CIA world factbook 2019-2020. Skyhorse Publishing.

Chapra, M. U. (2000). The future of economics : An islamic perspective. The Islamic Foundation.

Cole, J. R. (2009). Engaging the Muslim world. Palgrave Macmillan.

Dangolani, S. K. (2011). The impact of information technology in banking system (a case study in Bank Keshavarzi Iran). Procedia - Social and Behavioral Sciences, 30, 13-16. https://doi.org/10.1016/j.sbspro.2011.10.003

El-Bassiouny, N. (2014). The one-billion-plus marginalization: Toward a scholarly understanding of Islamic consumers. Journal of Business Research, 67, 42-49. https://doi.org/http://dx.doi.org/10.1016/j.jbusres.2013.03.010

Emslie, L., Bent, R., \& Seaman, C. (2007). Missed opportunities? Reaching the ethnic consumer market. International Journal of Consumer Studies, 31(2), 168-173. https://doi.org/10.1111/j.1470-6431.2006.00578.x

Ferguson, N. (2011). Civilization: The west and the rest. Allen Lane.

Furrer, O., Liu, B. S. C., \& Sudharshan, D. (2000). The relationships between culture and service quality perceptions: Basis for cross-cultural market segmentation and resource allocation. Journal of Service Research, 2(4), 355-371. https://doi.org/10.1177/109467050024004

Gait, A., \& Worthington, A. C. (2009). Attitudes, perceptions and motivations of libyan retail consumers toward Islamic methods of finance. SSRN Electronic Journal, 61(0), 1-17. https://doi.org/10.2139/ssrn.1370736

Haleem, M. A. (2011). Understanding the Qur'an : Themes and style. I.B. Tauris.

Jabnoun, N., \& Khalifa, A. (2005). A customized measure of service quality in the UAE. Managing Service Quality, 15(4), 374-388. https://doi.org/10.1108/09604520510606844

Jahanshahi, A. A., Gashti, M. A. H., Mirdamadi, S. A., \& Nawaser, K. (2011). Study the effects of customer service and product quality on customer satisfaction and loyalty. International Journal of Humanities and Social Science, 1(7), 253-260.

Janahi, M. A., \& Al Mubarak, M. M. S. (2017). The impact of customer service quality on customer satisfaction in Islamic banking. Journal of Islamic Marketing, 8(4), 595-604. https://doi.org/10.1108/JIMA-07-2015-0049

Kettani, H. (2019). The world muslim population. In The World Muslim Population. Jenny Stanford Publishing. https://doi.org/10.1201/9780429422539

Klementova, J., Zavadsky, J., \& Zavadska, Z. (2015). The measurement and evaluation of the service quality through customers 'satisfaction. Procedia Economics and Finance, 26(15), 126-130. https://doi.org/10.1016/s2212-5671(15)00893-x

Kotler, P. (2000). Marketing management, millenium edition. Prentice-Hall, Inc.

Kotler, P., \& Keller, K. L. (2012). Marketing management global edition. Pearson Higher Education.

Kwak, C. (2017). Gap analysis for improving service quality of service centers in South Korea. International Journal of Business and Social Science, 8(3), 51-56.

Ladhari, R. (2009). A review of twenty years of SERVQUAL research. International Journal of Quality and Service Sciences, 1(2), 172-198. https://doi.org/10.1108/17566690910971445

Lewis, A. (2010). Service quality model evaluation. Journal of Transport Logistics, 34, 235-254. 
Lovelock, C., \& Gummesson, E. (2004). Whither services marketing?: In search of a new paradigm and fresh perspectives. Journal of Service Research, 7(1), 20-41. https://doi.org/10.1177/1094670504266131

Lovelock, C., \& Wright, L. (2007). Principles of Services and Management. Pearson.

Masood, O., Aktan, B., \& Amin, Q. A. (2009). Islamic banking: A study of customer satisfaction and preferences in non-Islamic countries. International Journal of Monetary Economics and Finance, 2(3-4), 261-285. https://doi.org/10.1504/IJMEF.2009.029063

Moeller, S. (2010). Characteristics of services - A new approach uncovers their value. Journal of Services Marketing, 24(5), 359-368. https://doi.org/10.1108/08876041011060468

Moon, H. R., Kobayashi, N., \& Suh, M. P. (2006). Porous metal-organic framework with coordinatively unsaturated $\mathrm{mn}$ II sites: Sorption properties for various gases. Inorganic Chemistry, 45(21), 8672-8676. https://doi.org/10.1021/ic0611948

Muley, M. (2009). The 85\% Niche: The Power of Women of All Colors - Latina, Black, Asian. Paramount Market Publishing, Inc.

Nederveen Pieterse, J. (2009). Representing the rise of the rest as threat: Media and global divides. Global Media and Communication, 5(2), 221-237. https://doi.org/10.1177/1742766509341616

Othman, A., \& Owen, L. (2001a). Adopting and measuring customer service quality (SQ) in Islamic Banks: A study of the Kuwait finance house. International Journal of Islamic Financial Services, 3(1),1-26. https://doi.org/10.3366/edinburgh/9780748621002.003.0005

Othman, A., \& Owen, L. (2001b). The multi dimensionality of carter model to measure customer service quality (SQ) in Islamic banking industry: A study in Kuwait finance house. International Journal of Islamic Financial Services, 3(4), 1-12.

Parasuraman, A. P., Zeithaml, V. A., \& Berry, L. L. (1988). SERVQUAL: A multiple-item scale for measuring consumer perceptions of service quality. Journal of Retailing, 64(1), 12-40.

Prasadh, R., \& Suresh, J. (2017). Customer satisfaction index model for Indian banking industry: A Qualitative Study. Asian Social Science, 13(1), 114. https://doi.org/10.5539/ass.v13n1p114

Rajendran, R. P., \& Suresh, J. (2017). Customer satisfaction index as a performance evaluation metric: A study on indian e-banking industry. International Journal of Business, 22(3), 251274.

Rama, A. (2018). Mengukur derajat keislaman ekonomi dan faktor pendorongnya: Studi kasus provinsi di Indonesia. Maqdis : Jurnal Kajian Ekonomi Islam, 3(1), 1-15.

Rasoul, A., \& Mohammad, M. (2011). Ranking e-banking service quality factors using a fuzzy TOPSIS approach: A study about automatic teller machine. Asian Journal of Busness Management Studies, 2(3), 101-109.

Riaz, U., Khan, M., \& Khan, N. (2017). An Islamic banking perspective on consumers' perception in Pakistan. Qualitative Research in Financial Markets, 9(4), 337-358. https://doi.org/10.1108/QRFM-03-2017-0020

Saharuddin, D., Meirison, Chusna, I., \& Mulazid, A. S. (2019). Capitulation and siyasah syar'iyah al-maliyah impact on economic stability of the 18th \& 19th Ottoman Turks. Qudus International Journal of Islamic Studies, 7(2). https://doi.org/10.21043/qijis.v7i2.4847

Sekaran, U. (2006). Research methods for business: A skill building approach. John Wiley \& Sons, Ltd. 
Siddiqui, M. M., \& Ba-Yunus, I. (1998). A report on the Muslim Population in the United States of America. Center for American Muslim Research \& Informa.

Sinclair, J. (2009). Minorities, media, marketing and marginalization. Global Media and Communication, 5(2), 177-196. https://doi.org/10.1177/1742766509340969

Solomon, Michael, R., Surprenant, C., Czepiel, J. A., \& Gutman, E. G. (1985). A role theory perspective on dyadic interactions : The service encounter. Journal of Marketing, 49, 99111.

Türkyilmaz, A., \& Özkan, C. (2007). Development of a customer satisfaction index model: An application to the Turkish mobile phone sector. Industrial Management and Data Systems, 107(5), 672-687. https://doi.org/10.1108/02635570710750426

Wilson, A., \& Frimpong, J. (2004). A reconceptualisation of the satisfaction-service performance thesis. In Journal of Services Marketing, 18(6), 471-481. https://doi.org/10.1108/08876040410557258

Yola, M., \& Budianto, D. (2013). Analisis kepuasan konsumen terhadap kualitas pelayanan dan harga produk pada supermarket dengan menggunakan metode importance performance analysis (IPA). Jurnal Optimasi Sistem Industri, 12(12), 301-309.

Yousfani, K., Solangi, H. A., \& Lakhiar, A. G. (2019). Application of gap model in finding service quality gaps: Comparative study on domestic and foreign banks operating in Pakistan. Advances in Economics and Business, 7(2), 92-100. https://doi.org/10.13189/aeb.2019.070204

Zeithaml, V. A., Parasuraman, A., \& Berry, L. L. (1985). Problems and strategies in services marketing. Journal of Marketing, 49(2), 33. https://doi.org/10.2307/1251563

Zhu, F. X., Wymer, W., \& Chen, I. (2002). IT-based services and service quality in consumer banking. In International Journal of Service Industry Management, 13(1), 69-90. https://doi.org/10.1108/09564230210421164 